Journal of Business Management and
Economic Research
2019, 3 (12) DOI: $10.29226 /$ TR1001.2019.173
Journal Homepage: $\underline{\text { https://www.jobmer.org }}$

\title{
EFFECT OF INNOVATION CAPITAL ON FINANCIAL PERFORMANCE OF FIRMS LISTED IN NAIROBI SECURITY EXCHANGE
}

\author{
Stephen Chelogoi \\ PhD, Student, Department of Accounting \& Finance, School of Business \& Economics, Moi University \\ stevechelo36@gmail.com
}

\section{Joel Tenai}

Senior Lecturer, Department of Accounting \& Finance, School of Business \& Economics, Moi University

\section{Josephat Cheboi}

Lecturer, Department of Accounting \& Finance, School of Business \& Economics, Moi University

\begin{abstract}
The purpose of this paper is to investigate the effect of innovation capital on financial performance of firms listed in Nairobi Security Exchange. The longitudinal research design was used. The study targeted 67 firms in Nairobi Security Exchange. Secondary data (financial reports) to obtain financial performance information from 48 firms from Capital Market Authority Statistical Bulletins and Nairobi Securities Exchange Handbook for a period of twelve years from 2006 to 2017. Both descriptive and inferential statistics were analysed on the data. Pearson's correlation coefficient, multiple regression and research hypotheses were tested using hierarchical multiple regression analysis which was adopted to assess the direct and indirect effects of Innovation Capital on financial performance. The study found a positive and significant effect between Innovation capital $(\beta=0.102 ; 0<0.05)$ and financial performance of firms listed at the NSE. The present study has provided significant evidence that will help in generating an additional improvement on the understanding of Intellectual components and their effect on the firm's financial performance. The relationship between innovation capital and firm performance provides a guide on how firms in developing countries can enhance their performance in a competitive environment. Unlike previous studies which focused on developed and emerging economies, this study centered on a developing economy, and the findings are consistent with the propositions of the resource-base-view theory
\end{abstract}

Keywords: Innovation Capital, Financial Performance 


\section{Introduction}

Recently, the complexities of the global business environment characterized by growing market competition and advancing technological developments, have created a high level of uncertainty among companies in all industries, reinforcing the need for corporate organizations to be more vigilant about the business success (Gavrea, Ilies, \& Stegerean, 2011). Concerning the intermediation aspect, firms ' financial performance has significant implications for countries ' economic development. Good financial performance reflects the investors ' investment (Palaniappan, 2017). It, in turn, fosters additional investment and leads to economic development.

A company improves its performance by acquiring or creating a resource or resource combination that allows it to outperform its competitors (Muhammad and Ismail, 2009). There really is no question that highperformance firms are those that evolve constantly, focusing on their workers ' skills, knowledge and technology instead of resources such as equipment. Intellectual capital has been dubbed the new engine for corporate development to generate new awareness (Muhammad and Ismail, 2009). Understanding the determinants of organizational performance is therefore important, as it makes it possible to recognize certain factors that should be treated with increased interest to improve the financial performance. It is increasingly recognized that any organization's success depends significantly on its employees ' understanding, implementation, and integration. Successful companies rely more on workers ' skills and knowledge than on tangible assets. Dženopoljac, Janoševic, \& Bontis, (2016) contend that the knowledge economy supports the fact that business depends on wealth creation through development, activity, and consumption of the company's intellectual capital.

The significance of Intellectual Capital (IC) has a world view of enhanced business results. Intellectual capital (IC) is considered a source of assets and financial performance driver, thereby establishing both market competitive advantage and sustainability. Intellectual capital (IC) is a term that has gained ground significantly because companies are increasingly designing models based on knowing where the human factor plays a central role (Shamsuddin et al., 2015). Despite IC's utmost importance and role in organizational performance, empirical research remains scarce to explore IC's individual dimensional effect on organizational performance. In addition, in developed nations, human capital has been studied extensively but less widespread in developing countries (Waseem \& Loo-See, 2018). Despite recognizing intellectual capital as a key business engine, it has not fully explored its profound impact within and outside the group. In particular, empirical studies on intellectual capital and organizational performance posed contradictory threads that yield inconsistent and inconclusive results of a study (Kariuki, 2014). 


\section{Literature Review}

The modern world compels business to look for new ways of gaining competitiveness. In the industrial era competitiveness was maintained due to more effective use of separate factors of production, in the postindustrial economy the key weight is being put on the creation and systematic development of the environment promoting generation and the implementation of innovations, focused on development, production and product/service support (Grigorieva, Yelenevab, Golovenchenkoc, Andreevd, 2014). Innovation is related to acquisitions and applications of expertise that can be turned into new financially profitable assets (McCann \& Ortega-Argilés 2013). Therrien et al. (2011) defined innovation as a intricate procedure linked to the improvements of the manufacturing processes alongside techniques, as being connected closely to the innovative ideas (i.e. stocks of (technical) knowledge), and to human capital. This includes businesses seeking to gain the distinctive technical skills and build on them.

Innovation and distinction is considered necessary for every company due to fierce competition in the industry, globalization and an acceleration in innovation in recent years. Businesses must use new possibilities to develop new goods and/or services and industries in order to reach market success and maintain a competitive edge (Tajeddini 2010). Innovation is described as' the implementation of new useful ideas.' The general term applies to different types of design, such as product development, the implementation of new engineering systems and management. This means the adoption of new technologies and/or procedures, based on customer preferences (Kalkan, Bozkurt, Arman, 2014), to increase productivity and overall profitability. The competitive edge has moved from conventional to digital capital in the modern corporate world. The globalization process and the that development in fields such as industrial engineering, IT and telecommunications have led to the situation (Osinski et al. 2017). This situation has emerged.

Innovation has long been considered necessary to improve added value, to promote the development of businesses along the value chain, to increase productivity and efficiency, to stimulate spillover effects of innovation and economic growth in general (Trajkovski, 2018). Technology also represents a major cornerstone of intangible human resources (OECD, 2012), with up to one-third of growth in production in the field (Van Ark et al., 2012). Innovation often represents today. Empirical research indicates that creative capital and business skills generally constitute roughly $80 \%$ or more of all technical capital in appreciation of their role in global economic growth and in the development of the firms (Corrado et al., 2009; van Ark et al., 2012). 
The company's ability to innovate is the main factor in terms of profitability. Capabilities of change drive companies to continually create solutions to adapt to changing market demands (Slater, Hult \& Olson, 2010). Innovative research argues that creativity is the main source of business success and sustainability in such an analytical and dynamic competitive environment. Empirical studies by various scientists have shown that ingenuity is a necessary element for firm success (Aas and pedersen, 2011; Grajkowska, 2011; Gunday etal.,2011; Kiriyama, 2013). Four forms of technologies are introduced in the OECD Oslo Manual (2005). These are creative goods, systems, organisations and markets. Product and process development, especially in the service industry, closely related to technological improvements. Service technology can also be described in the Oslo manual (2005) (Rothkopf \& Wald, 2011). Item, system demand and structure contribute to change in Financial Institutions (Deloitte, 2012, 2017; Schaerer \& Wanner, 2011).

Innovation would have a more dynamic and separate impact on business quality in service companies than in development (Lin, 2011). This is because it's invisible, disruptive, inseparable and unpredictable. In the past few decades, scientists have been committed to finding the connection between technology and market achievement. To order to evaluate business performance, analysts have used various kinds of financial and non-financial metrics. Innovation had a positive effect on business performance, proposed (Yildìz et al. 2014). Based on existing literature (Çakar and Ertürk 2010; Liao et al. 2010 and Lin 2007), it can be conceptualized that Innovation Capital as the potential of knowledge creation and accumulation to institutionalize something new in an organization, and valuate it from the aspects of product, process and management. Product innovation means providing differentiated or new products/services in the market and obtaining satisfaction from customers. Process innovation concerns providing new manufacture or service operation other than current ones in order to achieve better performance. Innovation Capital has been regarded as the sum total of knowledge resources of a firm. Innovation Capital and its components were demonstrated to contribute to a firm's competitiveness, innovativeness, financial, and non-financial performance (Phusavat et al. 2011; Sharabati et al. 2010; Shih et al. 2010; Hsu and Fang 2009; Kang and Snell 2009; Kong and Thomson 2009; Longo et. al 2009). Innovation is not a new phenomenon, as stated by Fagerberg (2004). Nevertheless, despite its significance, scholars have not given it due attention. Marques at al. (2011) emphasized that fostering competition among businesses would lead to better business and financial performance for firms. The complex role that business activity plays in fostering innovation and technology, economic growth and jobs is shown by empirical evidence (Audretsch et al., 2006; Van Stel, 2006). The hypothesis guiding this paper is formulated as shown below. 
Ho: Innovation capital has no significant effect on financial performance of listed firms in Nairobi Security Exchange

Ha: Innovation capital has a significant effect on financial performance of listed firms in Nairobi Security Exchange

\subsection{Theoretical Perspective}

This paper is grounded on three theories namely the Agency Theory, Resource-based theory and the dynamic capabilities theory. Agency theory derived from economic theory. Alchian \& Demsetz first introduced it (1972) and expanded it further through Jensen and Meckling (1976). The key agent's role is established by Agency philosophy, while investors are the faces, while the manager is the person who is hired to run the company on behalf of the principal (Clarke, 2004). This theory separates ownership and control of firms. The shareholders are the directors inside the companies, whereas the managers are the agents and the company's board always play a dominant role by taking care of the investors expectations (Jensen \& Meckling, 1976). A pure agency relationship could be the connection between the stakeholders, the owners of the company and the chief executive. According to the theory of the Agency, managers (CEOs) have additional company data due to operational management over the company compared to the owners of the company.

Accordingly, at the expense of shareholders (owners) wealth, managers could act expeditiously and look for personal rents. The subsequent loss to the wealth of shareholders is called the price of the agency. This theory assumes the individualistic, opportunistic and greed of managers (Davis, Schoorman, and Donaldonson, 1997). On the basis of these assumptions, the idea advises the organization to put less governance in the hands of managers of the Organization. The investors are guaranteed, in conjunction with Jensen and Mackling (1976), that the best judgments can be generated by the managers provided that appropriate opportunities are given and only if the agent is monitored. By addition, the Agency's theory assumes that supervisors and subordinates are divergent and are mainly greedy and selfish. Schmidt and Posner (1983) state that longevity is completely related to tenure as long as it gives rise to a strong dedication to company values. In addition, by demonstrating the tenure mechanism influencing firm performance, Simsek (2007) asserted that long-tenured CEOs have positive impacts on firm performance. This tenure influences firm performance notwithstanding its ability of the CEO to cope with risk-taking activities. Conversely, an additional come occasionally comes with risk, and long-tenured CEOs can establish an improved trade-off that maximizes risk-taking returns as short-tenured CEOs do. 
The resource based (RB) theory is considered the pioneer that focused on the importance of intangible assets for firms (Barney, 1991). In this philosophy, the underlying premises are that both the measurable and the intangible assets are the competitive advantage of the commercial company. The intangible assets in this concept must be distinctive, inimitable and can create a competitive edge that is sustainable for the company. It assumes that the performance of tangible properties relies on immaterial asset quality and vice versa. A company's financial wealth has long been known as real and intangible assets. The theory has been mainly directed at immaterial capital over time (Reed et al., 2006). These authors argue that intangible assets or IC equities actually contribute to healthy firms ' competitive advantage. It says that every business can trad and replace natural resources such as shops, installations, and financial assets at any time. Youndt et al. (2004) reaffirmed that it is only IC that contributes greatly to income development and therefore provides a strategic advantage to knowledge economy firms. This argument was further reinforced.

Including the theory of Kolachi and Shah (2013) along with the atomic number 37 hypothesis, which notes that IC is central to every young and established business in more developed countries, this theory helps explain the connection of IC with the success of an entity. They primarily claim on the basis of this principle that IC contributes significantly to a company's financial output, notwithstanding the position of an entity, i.e. both developed, that and borders markets. This is in accordance with the World Health Organization's statement of Zéghal and Maaloul (2010) who note that companies will generate additional income and utilize their strategic resources for instance the IC. When assessing a competitive advantage of a company, the principle of RBV considers four (4) important features: longevity, consistency, transferability and replicability. The theory takes the view that companies are heterogeneous in terms of resources, capabilities or funds. Some of these resources are not readily tradable - for example tacit know-how and reputation (Teece, 2007). Therefore, from the RBV perspective, firms possess not only heterogeneous resources, but also sticky resource bundles. The resource heterogeneity results from their immobility and nontradability in the factor markets making them difficult to accumulate and imitate.

The RBV theory leaves out the process of resource development and adaptation to the external environment. This is that dynamic capabilities bridge. They alter the resource base in relation to the changing environment (Zahra \& George, 2002) and therefore are more valuable in unstable environments. They may create market change as opposed to just respond to it (Eisenhardt \& Martin 2000). The proponent for resource-based philosophy is Penrose (1959). In this theory, the sustainability of the company's performance and competitiveness is dependent upon the resources and capabilities at its disposal (Wernerfelt, 1984; Peteraf, 1993). Mahoney, (1995) posits that if companies are to develop, they must collect, 
marshal and effectively use their assets strategically. This implies that performance is a matter of strategizing. Companies can enhance their performance by strategically differentiating their products and services (Collins \& Porras, 2000).

The Dynamic Capabilities Theory is an extension of Penrose's capital-based view (RBV) (1959). Flexible capacities and RBV combine expectations, but former ones may help us understand the transformation of a company's resource inventory for firm performance over time. Dynamic capability approach means that productive companies need individuals who demonstrate prompt, quick and flexible development in the management skills, so that internal and external competencies are easily organized and implemented (Teece et al, 1997). Intrinsically, a particular capacity to differentiate and hard to replicate should be enhanced to a client in a strategic way (Teece et al., 1997). Like RBV, which uses heterogeneous, irreproducible tools, DCV notes that the nature of expertise and capacities is in the architecture and social control mechanisms that are created by a company's assets and formed by its methods. Given RBV's ability to describe, however, an organization can use its intangible capital to devise and execute a valuable strategy that provides efficiency, however, the approach lapsed at intervals rationalization on and why certain businesses outstrip others in rapidly dynamic environments (Carlos, 2011). As a consequence, Dynamic Capabilities Read (DCV) emerged as a coordinating framework for completing and complementing the RBV when deciding to provide superior firm output in such unannounced and increasingly dynamic sceneries (Teece and Pisano, 1994).

Resources are tangible and intangible assets, generally outlined, that the firm will develop and effectively management. Resources, that embrace the abilities of the firm's staff, its instrumentality, and also the collective skills of the organization, generate streams of services that the firm will deploy. Schumpeter's work in 1934 contributed to the concept of dynamic capabilities (Camison and Monfort-Mir, 2012; Chinese Monetary Unit et al., 2013). The Schumpeterian view hypothesized that what affects performance is the activities and skills that compose a company's basic structure as well as the organic mechanism that interacts between the world and a company (Makkonen et al., 2014). The study also showed that new blend of skills and capital into prevailing operational capacities forms the basis for evolutionary mobility (Jiao et al., 2013; Makkonen et al., 2014).

Dynamic expertise approach suggests thriving organizations that provide a swift, scalable response, and leadership resources to organize and deliver internal and external skills efficiently (Teece et al., 1997). Therefore, a selected ability to respond strategically to the requirements of a client should be improved, distinctive and difficult to duplicate (Teece et al., 1997). DCV maintains that the crux of talents and 
capacities does not change in the structural and social control structures that are generated by and carried out by the asset roles in a business, unlike RBV, which has been based on heterogeneous and reproductive capital. Firms will develop and effectively manage both the tangible and intangible resources. Resources, that embrace the abilities of the firm's staff, its instrumentation, and also the collective skills of the organization, generate streams of services that the firm will deploy. Dynamic skills reside, in part, with individual managers and particularly the highest management team, enabling the World Health Organization to take part in detective work and exploit opportunities. At a certain critical juncture, the agility of a corporate executive and also the high management team to identify a key development or pattern, then delineate a response and lead the company forward, could be the most outstanding feature of the diverse capabilities of the company. The approach to dynamic capabilities helps to justify why intangible assets, together with the collective data and capabilities of a firm, have always been the most valuable asset category in a variety of industries. The rationale is that information, capabilities and alternative intangibles do not tend to be constrained; they are usually hard to imitate. In today's business climate, defined by fast changes in economic and political systems in phenomena like financial processes and e-business hyper-competition, rapid technological advances, companies can build and model specific strategies that can produce resources, expertise and competitive advantage over a lasting period (Marr et al. 2004). Tseng and Lee (2014) concluded that it is an indispensable need because of the incapacity of the existing Standard Strategic Management Framework to tackle differences in the reliability and use of its information tools to obtain a human adaptive potential that can react quickly to changes in its settings. The foundation for sustainable business success therefore lies in businesses ' agile abilities to develop internal and external capital and expertise to fit evolving conditions quickly (Zahra \& George, 2002).

\section{Research Design}

The research design conjointly affords the rules and directions to be followed when dealing with the research drawback (Polit \& Hungler 1993). Collis et al, (2003) note that a search style could be a manner of coming up with knowledge assortment so as to conduct associate degree inquiry and extract the foremost important and valid findings. This study ran the Panel regression model. Panel multivariate analysis is a regression that involves the amalgamation of time series and cross-sectional knowledge. Panel regression is a crucial methodology of longitudinal analysis as a result of it permits for variety of regression analyses in each spatial (units) and temporal (time) dimensions. Panel regression forestall the information loss 
because of the collection; it reduces the quantity of multiple regression issues and it displays higher degrees of significance (Baltagi, 2001 and Balestra, 1992).

Panel regression has the advantage to require into thought each cross-sectional variations and variations over time during a time-series dimension. Not solely is it a lot of informative than one-dimensional ways, however results may also a lot of simply be generalized because it reduces attainable impacts of temporal errors that might have an effect on the information (Beattie et al., 2006, Bryman \& Bell, 2011 and Bhattacherjee, 2012). This method conjointly permits management of individual heterogeneousness, creating it probable to eliminate partiality originating from the existence of individual effects (Hsiao, 2003, Baltagi 2005, Bjron \& Friss, 2013). The panel analysis has been used antecedent by alternative students (Heshimite, 2001; Gujariti, 2003 and Baltagi 2005). Therefore, the supply of perennial observations on an equivalent cross-sectional unit ensures the viability of comparatively a lot of realistic models (Bjron \& Friss, 2013). According to Park (2011), panel knowledge is ideally measured at regular intervals like months or years. This study supported a panel knowledge analysis of the Nairobi exchange between 2006 and 2017. The study endeavoured to illuminate the effect of intellectual capital on firm monetary performance (measured in terms of Tobin's Q) on one hand and tempered by CEO tenure so as to induce a handle on the time ordering of variables and to trace individual trajectories over time. Panel style was an ideal approach to be utilized in this study

\section{Target Population and Sample}

The study target population included all firms listed in the Nairobi Security Exchange in Kenya. According to CMA reports (2016), there are 67 listed firms in Nairobi Security Exchange by 2006-2017. However, listed firms that were included in the study were those that were fully trading on NSE during the study period. Those firms that listed after 2006 and those that were suspended were omitted from the study. Firer and William (2003) and Shiu (2006) posit that firms with a negative net worth or reduced value of Human or Structural Capital did not form part of the study sample. Companies whose information was unreachable (absent from the yearly financial records, due to deregistration or other reasons) were exempted from the sample. A sample comprising of 48 firms that met all the above criteria were available for this study, thus yielded 576 firm-year observable data. 


\subsection{Empirical Model}

The study endeavoured to use hierarchical regression models to test the direct effect of the study variables. The investigation models were as follows:

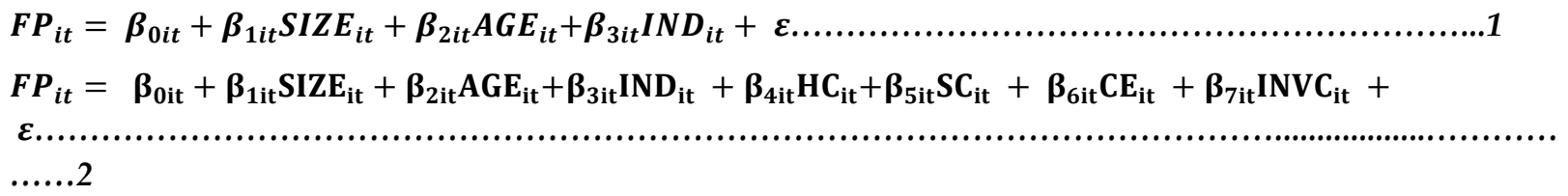

Where:

FP it is dependent variable (firm performance as measured by Tobin's $Q$ ratio)

$\mathrm{HC}_{\mathrm{it}}=$ human capital of firm $i$ at time $t$.

$\mathrm{SC}_{\mathrm{it}}=$ structural capital of firm $i$ at time $t$.

$\mathrm{CE}_{\mathrm{it}}=$ capital employed of firm $i$ at time $t$.

INEC $_{\mathrm{it}}=$ innovation capital of firm $i$ at time $t$.

SIZEit $=$ firm size of firm $i$ at time $t$.

AGEit=Firm age of firm $i$ at time $t$.

IND $D_{\mathrm{it}}=$ Industry of sector $i$ at time $t$. of firm $i$ at time $t$.

$\beta_{0}=y$-intercept of firm $i$.

$\varepsilon_{\mathrm{it}}=$ error term error term of firm $i$ at time $t$. (random variation due to other unmeasured factors).

\subsection{Measurement of Variables}

A characteristic of research is calculating variables in the theoretical framework (Sekaran and Roger, 2013). The method of assigning numbers to that analysis parameter (Lee and McKinney 2012), is simply the measurement of a variable. Leedy and Ormrod (2010) have argued that the scientist cannot test the theories and find solutions to the problems of study if the variables are evaluated in any manner. The dependent variable was firm financial performance. The present study used Tobin's $Q$ the dependent variable; that acted because the proxy for firm financial performance. Tobin's $Q$ ratio, as reflected in its investment strategies, is an indicator of a business ' growth opportunities. It contrasts the market price of the product with the replacement cost of the assets of the company. It also means the lower the actual return on investment, the higher the value of $Q$.

Using Tobin's Q overcomes some of the book-to-market (B / M) related problems using the cost to replace capital while estimating the value of the company. Tobin's $Q$ is measured by the value of the firm divided by replacement value of its assets (Chung \& Pruitt, 1994). The utilization of Tobin's Q quantitative relation 
of value to value neutralizes the impact of various policies from one company to a different company or from one country to another country. A $Q$ between zero and one is taken into account as low and means the worth of the firm is under its assets and would implicate that the firm can be undervalued. Tobin's $Q<$ 1 Description found in undervalued stocks, management has failed to manage the company's assets, with low potential for investment growth.

Tobin's $\mathrm{Q}=1$ Describe that a firm security are not through in the average circumstances, management is static in asset management. Tobin's $Q>1$ Describing that securities in condition overvalued, management succeeded in managing the assets of the company, high investment growth potential (Tobin \& Brainard, 1968 and Tobin, 1969; Lang, Stulz \& Walkling, 1989 and Fiakas, 2005).

Tobin's $\mathrm{Q}=\frac{\text { market value }+ \text { total debt }}{\text { total assets }}$

The Value-Added Intellectual Capital (VAICTC) method used in this study to measure the independent variable was developed and used by Pulic (1998 2001 and 2002a, b). Other scholars who have used VAICTC method include (El-Bannany, 2008, Kamath, 2007, Goh, 2005, Mavridis, 2005). VAICTC is the sum of total of the three ratios calculated as the sum of $\mathrm{HCE}, \mathrm{SCE}$ and $\mathrm{CEE}$, and indicates the intellectual; capability of the listed firms. Independent variables are value-added intellectual coefficient (VAIC) factors. According to VAICTC the total revenue (out) and total expenses (input) represents the value that the firm produces by employing its resources and capital. This study adopted the same steps as were done by other scholars in computing VAICTC efficiency.

Independent Variables: Value Added Intellectual Coefficient (VAICTC) Components:

i) Innovation capital efficiency (INCE)

The procedures for computing VAIC are: first is to calculate Value Added, which is derived from the difference between outputs and input. Value added (VA) refers to the newly created value, calculated for a given firm during a particular fiscal year. It is obtained as the difference between inputs and outputs of the operating activities of the firm.

$V A_{i}=$ OUTPUT - INPUT

Where OUTPUT is the sum of earnings from sales throughout a financial year. While INPUT = the total costs and expenses incurred by the firm during that particular fiscal year (excluding labor expenses, which are employees' compensation and all expenses that are related to their training and development. In this research, output comprised the sum of all earnings per financial year in every participating company. On 
the other hand, input comprised the sum of overheads and expenditures minus workforce salaries and costs incurred for their on-the-job induction. In this analysis, labour expenses are considered an investment and not cost.

In computing INCE $\mathrm{i}_{\mathrm{i}}$ the study evaluated a firm's INCE divide by firm's book value of common stock.

$\mathrm{INCE}_{\mathrm{i}}=\mathrm{INC} / \mathrm{VA}-\mathrm{-}-\mathrm{-}-\mathrm{-}$

This study controlled for three variables. Variables that may affect the financial performance were controlled during the analysis process to elicit the net effects of intellectual capital and financial performance. These variables have been extensively used in previous studies and have confirmed the potential influence on firm performance.

Firm size: the size of the company was chosen because it was essential for future disclosure research (Hossain, 2008). Firm size is chosen because it has been found by previous studies to be related to the difficulty and information processing demands placed on CEOs (Henderson and Fredrickson 1996). Measuring the size of the company was consistent with other studies done by Haniffa and Cooke (2005), Freedman and Jaggi (2005). The size of the firms has an effect on their IC components and financial performance of the company (Nimtrakoon, 2015; Chan, 2011). Previous studies calculating the size of the organization's total assets by popular logarithm include Pouraghajan, (2012), Iavorskyi, (2013) and Meressa, (2016). The natural logarithm of total assets for measuring the firm size in this analysis, as it is firmly established in previous research, and that firm asset as such appear as a logical denominator for size as such. The size of the company was referred to as FSize.

Firm age: The age of the company was denoted as FAge. It was determined by counting the company's age from the establishment date of the said company. Firm age is usually a monitor or an econometric device, and it is sometimes a proxy for non-observed variables like education (Pastor and Veronesi, 2003). The finance literature also discussed age-related productivity problems, although the age and tenure of managers within the company could also trigger a suspicious relationship from different angles (Finkelstein and Hambrick, 1990). Ultimately, the literature on diversification indicates a relationship between age and profitability. Therefore, this study followed Fama and French (2001) and Pastor and Veronesi (2003) and concluded that firms were "born" on the NSE listing in the year of their first 
appearance. Consequently, the company's age is the number of years (plus one) that have already passed since the Company's IPO year.

Industry sector: The industry in which a firm is involved influences according to multiple studies, whether it's engaged in certain performance practices or not (Habbash, 2015). Some previous studies tracked the effects of industry simply by focusing on a single industry (Paek et al., 2013) or by distinguishing between manufacturing and non-manufacturing sectors only (Barnea \& Rubin, 2010; Waddock \& Graves, 1997; Loughran and Ritter, 1995). However, using manufacturing to create dummy variables by assigning "1" to firms in the manufacturing sector and "0" to the rest is one of the most common ways of controlling for a firm's performance. This study followed the same line with other scholars ' approaches to monitor the industry's specific effects on firm performance

\subsection{Data analysis}

For the presentation of data, mean, standard deviation skewness, and kurtosis was used. It offers statistical and graphical procedures for a clear and understandable way of summarizing a collection of data. Descriptive statistics enable the study in a sensible way to simplify large amounts of data. Descriptive statistics were used to explicitly summarize and understandably represent empirical findings (McDaniel and Gates, 2010). Correlation and multiple regressions analysis was also used to estimate the causative relationship between intellectual capital and firm performance what is more as various variables chosen. For the analysis of correlation and regression, SPSS version twenty package was used. The statistic indicates the direction of the affiliation, whether or not or not positive or negative (Bryman \& Bell, 2007; Field, 2009). This research determined the coefficient of multiple correlations or the explanatory power of the modified model " $\mathrm{R}^{2}$ " to check the reliability of the model's linear fit. Multiple regression models were used here because many independent variables existed. Furthermore, with the range of explanatory variables in the model, this figure consistently increases. The analysis further examined the derivative of $\mathrm{R}^{2}$ called the modified coefficient of correlation in this context. In the analysis, the determination coefficient (R-square) was used to demonstrate the model's predictive and explanatory strength. The thesis therefore utilized hierarchical multiple regression modelling to check the research hypotheses.

The use of hierarchical multiple regression analyses to check for moderator influence was observed by Baron and Kenny's (1986) and Frazier et al. (2004). Moderation occurs when the relationship between two variables varies depending on the level of another variable in magnitude, direction, or statistical significance. To evaluate the effects between the variables and to test the hypotheses, a hierarchical multiple 
regression analysis was done. In order to test the effects of certain predictors, regardless of the influence of others, the hierarchical regression model is used to determine a fixed order of entry for variables (Pallant, 2010). Hierarchical model of regression was used to achieve this. Only some of the variables were used simultaneously throughout each point in the hierarchical regression analysis. At each step, $\mathrm{R}^{2}$ was determined to show the incremental change with the inclusion of the most recently entered predictor and applied exclusively to the predictor.

\section{Findings and Discussion}

Table 1 provides a summary of the descriptive statistics of the dependent and independent variables for the 48 firms listed in NSE from the year 2006 to 2017 with a total of 576 observations. The table shows the mean, minimum, maximum, standard deviation, skewness, Kurtosis and number of observations of the dependent and independent variables.

Table 1: Descriptive Statistics

\begin{tabular}{lccccccc}
\hline & $\begin{array}{c}\text { Total penal } \\
\text { observations }\end{array}$ & Mean & Sd & Max & Min & Skewness & Kurtosis \\
\hline Tobin Q & 576 & 1.67 & 0.88 & 4.42 & 1.33 & 1.89 & 1.80 \\
HCE & 576 & 11.57 & 11.60 & 75.33 & -35.66 & 1.77 & 2.19 \\
SCE & 576 & 1.51 & 5.90 & 74.33 & -0.13 & -1.23 & 2.32 \\
CEE & 576 & 16.89 & 19.23 & 120.05 & -55.66 & 2.05 & 3.32 \\
INCE & 576 & 2.93 & 4.57 & 25.89 & 0.27 & -0.75 & -0.06 \\
VAIC & 576 & 3.52 & 0.55 & 8.72 & 0.57 & 0.99 & 2.23 \\
IND & 576 & 5.78 & 3.34 & 1.00 & 0.00 & 0.11 & 1.73 \\
FSize & 576 & 6.17 & 0.92 & 8.89 & 4.10 & -0.52 & 7.12 \\
FAge & 576 & 55.50 & 32.56 & 165.00 & 14.00 & 0.83 & 2.16 \\
\hline
\end{tabular}

Source: Research data (2018)

As can be seen in Table 4.1 above, the mean values of all variables range from a minimum of -55.66 for CEE as measured by the significance-added ratio of the capital employed to a maximum of 165.00 for the firm age as measured by the firm's period to the current year. Over the period under study, the mean of VAIC achieved value greater than one. It means that sample of enterprises creates value. The minimum and maximum Tobin's $Q$ of companies listed in NSE Kenya are 1.33 and 4.42 respectively. The table also indicates that the mean value for the dependent Tobin's $Q$ variable is 1.67, suggesting greater efficiency than average. The standard deviation from either the dependent Tobin's $Q$ variable is 0.88 , indicating that economic performance volatility varies only by 88 percent from the median. Human capital is the highest 
enhancing value of intellectual capital. The mean value of variables in economic performance suggests the general financial soundness of Kenya's NSE market. Tobin's Q can measure long-term performance that Kweh, Lu, Wang (2014) anticipated. Tobin's Q is a comprehensive analysis of the company's assets and a strong method to reflect the competitive strengths of the firm; it could also reveal the earnings achieved from the investment in Aramburu, \& Saenz, (2011).

The average value of 16.89 capital employed efficiency illustrates the high quality of the NSE's financial assets. In relation, being a high-profile NSE, employed capital has been a major contributor to NSE performance overall excellence. Concerning the independent variables, the mean value suggested by CCE is more effective in wealth creation during the study period than HCE, INCE, and SCE. However, if the components are examined individually, it is evident that the efficiency in capital employed (mean=16.89) is more efficient compared to the human capital efficiency (mean 11.57), innovation capital efficiency (mean= 2.93), and structural capital (mean=1.51). The findings reveal that listed firms invest significantly in their financial assets and human capital to exploit the knowledge and skill of their employees to improve on their overall performance. The findings of Firer \& Williams (2003), Ho \& Williams (2002) corroborate this.

\subsection{Correlation results}

Table 2: Pearson Correlation Coefficients Result

\begin{tabular}{|c|c|c|c|c|c|c|c|c|c|c|}
\hline & 1 & 2 & 3 & 4 & 5 & 6 & 7 & 8 & 9 & 9 \\
\hline 1. Tobin's & 1.0000 & & & & & & & & & \\
\hline 2. $\mathrm{HCE}$ & $0.1592^{*}$ & 1.0000 & & & & & & & & \\
\hline 3. CEE & $0.6256^{*}$ & $0.4775^{*}$ & 1.0000 & & & & & & & \\
\hline 4. INCE & $0.1883^{*}$ & $0.3369^{*}$ & $0.2189^{*}$ & 1.0000 & & & & & & \\
\hline 5. SCE & $0.1689^{*}$ & $0.1391^{*}$ & $0.0845^{*}$ & $0.1925^{*}$ & 1.0000 & & & & & \\
\hline 6. VAIC & $0.142^{*}$ & $0.587^{*}$ & $0.977^{*}$ & 0.237 & -0.177 & 1.0000 & & & & \\
\hline 7. Industry & $-0.3987^{*}$ & $-0.1637^{*}$ & $-0.4659^{*}$ & $-0.1697^{*}$ & $-0.0749^{*}$ & 0.018 & 1.0000 & & & \\
\hline 8. Firm Size & $-0.4372^{*}$ & 0.0628 & $-0.4247^{*}$ & 0.0630 & $0.0830^{*}$ & $-0.080^{*}$ & $0.0927^{*}$ & 0.0214 & 1.0000 & \\
\hline 9. Age & $-0.0906^{*}$ & $-0.2141^{*}$ & $-0.2609^{*}$ & $-0.1641^{*}$ & 0.0243 & 0.038 & $0.4535^{*}$ & $\begin{array}{c}- \\
01160 *\end{array}$ & $\begin{array}{c}- \\
0.0618\end{array}$ & 1.0000 \\
\hline
\end{tabular}

Correlation is significant at ${ }^{*} 0.05$ level; $\mathrm{N}=576$

Pearson moment correlation was used, depending on the level of measurement, to describe the relationship between independent and dependent variables. Using the Pearson product-moment correlation coefficient, the relationship between the independent variable and the dependent variable has been investigated. The 
findings of the Pearson correlation in Table 2 showed that the financial performance of human capital was also associated positively as evidenced by a coefficient of $r=.1635$ which is also significant at $\mathrm{p}<0.05$. This proves that high-quality human resources have been the backbone for the efficient utilization of intellectual capital assets. The output also shows that structural capital efficiency is positively related to financial performance, with a coefficient of $r=.1689$ which is also significant at $\mathrm{p}<0.05$. Structural capital tended to have a lower influence on the performance of the firms than that of human capital This corroborates with the research study by (Khalique et al., 2011).

The correlation results also indicated that the efficiency of capital employed is positively related to financial performance as demonstrated by a coefficient of $r=0.625$ significant at $\mathrm{p}<0.05$. It indicates that an improvement in physical capital's value-creation capacity will impact financial performance. The findings show that capital employed appears as the most important component of intellectual capital accounting in influencing the financial performance of publicly traded firms in NSE, capital employed is a primary and very critical component of intellectual capital because it is a very important source of superior performance. This is in inconsistency with previous studies (Bontis, 1998; Stewart, 1997) that ranked human capital as a first and structural capital as second contributors to business performance respectively.

Innovation capital efficiency is also positively related to financial performance with a coefficient of $\mathrm{r}=.1883$ of Pearson Correlation, which is significant at $\mathrm{p}<0.05$. Firm size was also negatively associated with financial performance, with an $\mathrm{r}=0.4372$ coefficient that is also important at $\mathrm{p}<0.05$. Firm age had a negative correlation with financial performance based on the coefficient of $r=0.091$ of Pearson Correlation that is significant at $\mathrm{p}<0.05$. In contrast, the industry sector has a negative correlation with a coefficient of $\mathrm{r}=0.398$ in financial performance, which is significant at $\mathrm{p}<0.05$. From the above, INCE, SCE, CEE, HCEI, firm size, firm age, and firm financial performance have a linear relationship. It offered more room for multiple analyzes of regression.

\subsection{Testing for Fixed Model or Random Effect}

To find out which estimation effects (between fixed and random) produced superior results, a Hausman test was carried out for the specified panel regression model. The test was conducted against the null hypothesis that the random effect model Both fixed and random effects were used to test the hypothesis and Hausman tests were used to determine which model the hypothesis was investigated. In the specification for fixed effects, $\mathrm{r}$ squared was 0.2603 that also implies that intellectual capital contributes to $26.03 \%$ of economic performance. 
Table 1 findings showed that innovation capital efficiency would have a beneficial and significant impact on financial-economic performance $(\beta=0.104, \pi<0.05)$. In specific, an increase of 0.104 units in innovation capital efficiency leads to an increase with the same unit in significant economic results. The $t$-value $=2.90$ which implies it's more than the recommended error.

\section{Table 3: Fixed model}

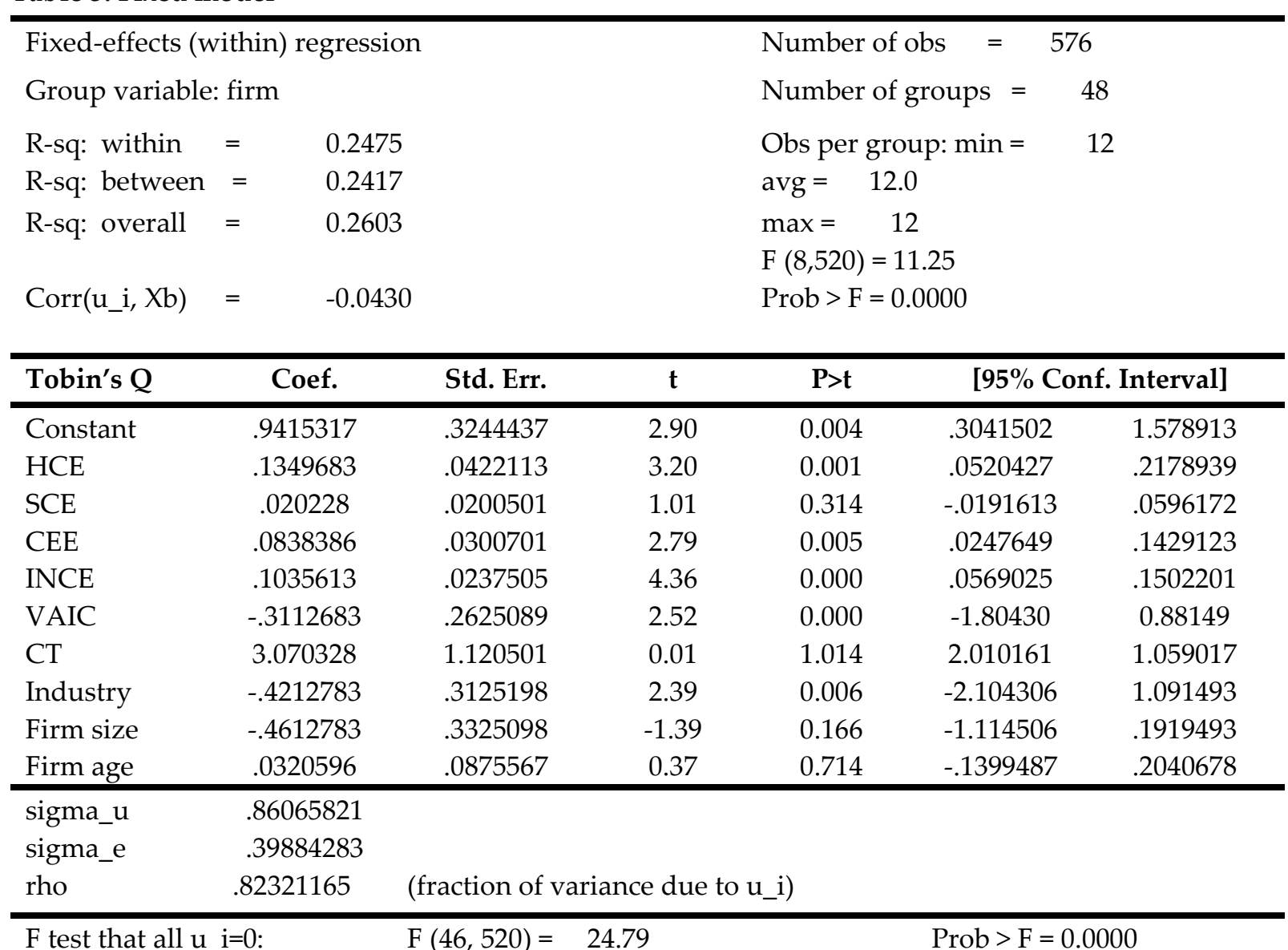

Using Generalized Least Squares (GLS), RE models can be calculated. R Squared was 0.5065 from the RE model, indicating that the intellectual capital components ((human capital, structural capital, capital employed and innovation capital) explains $50.65 \%$ variation in the financial performance of listed firms in Nairobi securities. Results revealed that innovation capital $(\beta 3=0.102, p<0.05)$ had a significant effect on organizational financial performance. It implied a decrease in the firm financial performance of up to 0.137 units for each capital employed and an increase in the firm financial performance of up to 0.102 units for each innovation capital unit. The control effect findings showed that the industry had a positive effect on the financial performance of the publicly traded companies $(\beta=-0.540, \pi>0.05)$, while the size of the 
company $(\beta=-0.186,(\beta=-0.186, \varrho>0.05)$ and firm age $(\beta=-0.07, \varrho>0.05)$ had no significant effect on firm financial performance.

Table 4: Random effect

\begin{tabular}{|c|c|c|c|c|c|c|}
\hline Random-eff & GLS regres & & & Numb & $\mathrm{bs}=576$ & \\
\hline Group varia & firm & & & Numb & roups $=48$ & \\
\hline R-sq: withi & .5332 & & & Obs $p$ & $\mathrm{p}: \min =12$ & \\
\hline R-sq: betwe & 0.5470 & & & $\operatorname{avg}=$ & & \\
\hline R-sq: overa & .5065 & & & $\max =$ & & \\
\hline $\operatorname{corr}\left(u_{-} \mathrm{i}, \mathrm{X}\right)$ & (assumed) & & & $\begin{array}{l}\text { Wald } \\
\text { Prob > }\end{array}$ & $\begin{array}{l}111.97 \\
0000\end{array}$ & \\
\hline Tobin's Q & Coef. & Std. Err. & $\mathrm{t}$ & $\mathrm{P}>\mathrm{t}$ & [95\% Con & terval] \\
\hline Constant & 1.046697 & .3527195 & 2.97 & 0.003 & .3553793 & 1.738015 \\
\hline HCE & .0645668 & .0411294 & 1.57 & 0.116 & -.0160453 & .145179 \\
\hline CEE & .1369476 & .0294213 & 4.65 & 0.000 & .0792828 & .194612 \\
\hline INCE & 1023792 & .02415 & 4.24 & 0.000 & .0550462 & .149712 \\
\hline SCE & .0304559 & .0204509 & 1.49 & 0.136 & -.009627 & .070539 \\
\hline VAIC & .162358 & .017890 & 3.06 & 0.000 & .045078 & .176945 \\
\hline $\mathrm{CT}$ & .002379 & 1.02059 & 2.04 & 0.000 & .0560462 & .138612 \\
\hline Industry & -.5396242 & .1771065 & -3.05 & 0.002 & -.8867466 & -.192502 \\
\hline Firm size & -.1864135 & .3375723 & -0.55 & 0.581 & -.848043 & .4752161 \\
\hline Firm age & -.0074739 & .082397 & -0.09 & 0.928 & -.1689692 & .1540213 \\
\hline sigma_u & .5503982 & & & & & \\
\hline sigma_e & .39884283 & & & & & \\
\hline rho & 65569079 & (fraction & ace du & & & \\
\hline
\end{tabular}

\subsection{Correlation results}

Assessment of correlation is a means of measuring relationships between variables and causes. Pearson $\mathrm{r}$ is the most commonly used form of a correlation coefficient, often considered as a linear or productmoment correlation.

Table 5: Correlation results

\begin{tabular}{|c|c|c|c|c|c|c|c|c|c|c|}
\hline & 1 & 2 & 3 & 4 & 5 & 6 & 7 & 8 & 9 & 9 \\
\hline 10. Tobin's & 1.0000 & & & & & & & & & \\
\hline 11. HCE & $0.1592^{*}$ & 1.0000 & & & & & & & & \\
\hline 12. CEE & $0.6256^{*}$ & $0.4775^{*}$ & 1.0000 & & & & & & & \\
\hline 13. INCE & $0.1883^{*}$ & $0.3369^{*}$ & $0.2189^{*}$ & 1.0000 & & & & & & \\
\hline
\end{tabular}


Journal of Business Management and Economic Research (JOBMER), vol.3, issue.12, pp.38-59

$\begin{array}{lcccccccccc}\text { 14. SCE } & 0.1689^{*} & 0.1391^{*} & 0.0845^{*} & 0.1925^{*} & 1.0000 & & & & & \\ \text { 15. VAIC } & 0.142^{*} & 0.587^{*} & 0.977^{*} & 0.237 & -0.177 & 1.0000 & & & & \\ \text { 16. Industry } & -0.3987^{*} & -0.1637^{*} & -0.4659^{*} & -0.1697^{*} & -0.0749^{*} & 0.018 & 1.0000 & & & \\ \text { 17. CT } & 0.2382^{*} & -0.0226 & 0.1263^{*} & 0.0343 & -0.1087^{*} & 0.531 & -0.0673 & 1.0000 & \\ \text { 18. Firm Size } & -0.4372^{*} & 0.0628 & -0.4247^{*} & 0.0630 & 0.0830^{*} & -0.080^{*} & 0.0927^{*} & 0.0214 & 1.0000 & \\ \text { 19. Age } & -0.0906^{*} & -0.2141^{*} & -0.2609^{*} & -0.1641^{*} & 0.0243 & 0.038 & 0.4535^{*} & - & - & 1.0000\end{array}$

Correlation is significant at ${ }^{*} 0.05$ level; $\mathrm{N}=576$

Pearson moment correlation was used, depending on the level of measurement, to describe the relationship between independent and dependent variables. The findings of the Pearson correlation in Table 4.10 showed that Innovation capital efficiency is also positively related to financial performance with a coefficient of $\mathrm{r}=.1883$ of Pearson Correlation, which is significant at $\mathrm{p}<0.05$.

\subsection{Regression Results}

The control variables are regressed with Tobin's $Q$ and secondly with a four-factor model like HCE, SCE, CCE, and INCE. Model 1 ran the three control variables and excludes IC components and the interaction variable in the model. The model has overall significance but its power to explain the total variation independent variable is good with about $26 \%$. Model 2 consists of four IC components (HCE, SCE, CCE, and INCE) and the controlling variable (firm size, industry, firm age). The analysis reveals that capital efficiency (CCE) and innovation capital efficiency (INCE) have a significant positive impact on Tobin's $Q$ values. The controlling variable (firm size, industry, firm age) all negative significant effect on the dependent variable. The regression results show that the financial performance of listed companies was influenced by both CEE and INCE.

Based on the findings in the Hausman test, the study will use a random effect to test hypotheses. The hypothesis guiding this paper is formulated as shown below.

Ho: Innovation capital has no significant effect on financial performance of listed firms in Nairobi Security Exchange

Ha: Innovation capital has a significant effect on financial performance of listed firms in Nairobi Security Exchange 
Findings showed that innovation capital had estimate coefficient was statistical significantly on $\beta 4=0.081$ ( $\mathrm{p}$-value $=0.000$ which is less than $\alpha=0.000$ hence it was concluded that innovation capital had a positive and significant effect on firm financial performance, suggesting that there was an increase in firm financial performance of up to 0.081 units per unit of innovation increase. This suggested that there was an increase of up to 0.081 unit of firm financial performance for each unit of innovation capital increase. Ultimately, the null hypothesis was discarded and it was concluded that innovation capital had a significant effect on the financial performance of publicly traded companies in NSE. This is in line with Kinot's (2009) findings which demonstrated that investment in technology, specifically research and development, contributed directly to a company's higher performance, as Slater et al. (2012) also cited. Benedetto and Mu's (2011) findings aligned with current findings that innovation-based technology creates new products that lead to high company performance. In particular, the findings of Anal et al. (2011) supported the conclusions of the current study in suggesting that the relationship between technology and rim financial performance is positive and significant.

\section{Conclusion}

The study concludes that innovation capital had a positive and significant effect on financial performance. Similar findings by OECD, (2005) clearly indicated that innovation capital is a key driver of productivity and economic growth. Besides, the reviewed literature has also shown that innovation capital contributes to a firm's competitiveness, innovativeness, financial, and non-financial performance (Phusavat et al. 2011; Sharabati et al. 2010; Shih et al. 2010). In the same vein, the findings from this study lend support to that of Huang and Liu, (2005) who investigated the relationship between innovation, IT and performance. Their study established that interaction between IT capital and innovation capital has a positive impact on performance. Evidently, the extant literature has confirmed that indeed innovation capital has a positive influence on firm performance. Overall, the study findings corroborate prior studies on innovation capital effects on firm financial performance measured by several proxies. 


\section{References}

Abdulsalam Al-Qaheri, F. H., \& Al-Khayyat, R. (2011). The Intellectual Capital Performance of Kuwaiti Banks: An Application of vaicTM1 Model. iBusiness, 3(1), 88-96.

Anghel, I.; Siminică, M.; Cristea, M.; Sichigea, M.; Noja, G.G. Intellectual capital and financial performance of biotech companies in the pharmaceutical industry. Amfiteatru Econ. 2018, 20, 631-646

Bontis, N. \& Fitz-enz, J. 2002. Intellectual capital ROI: A causal map of human capital antecedents and consequents. Journal of Intellectual Capital, 3(3):223-247

Bontis, N. (2002) "Managing organizational knowledge by diagnosing intellectual capital: Framing and advancing the state of the field" in World Congress on Intellectual Capital Readings, Bontis, N. (Ed.), Butterworth-Heinemann, Boston, MA, pp13-56

Bontis, N. and Fitz-enz, J. (2002) Intellectual Capital ROI: A Causal Map of Human Capital Antecedents and Con sequents. Journal of Intellectual Capital, 3, 223-247.

Bontis, N., \& Serenko A. (2009). A causal model of human capital antecedents and consequents in the financial services industry. Journal of Intellectual Capital, 10(1), 53-69.

Bontis, N., Keow, W. C. C., \& Richardson, S. (2000). Intellectual capital and business performance in Malaysians industries. Journal of Intellectual Capital, 1(1), 85-100.

Chen, F.C., Liu, Z. J and Kwen, Q. L (2014), "IC and productivity of Malaysian general insurance Economics modelling, vol 36, January Pg 413-420.

Chen, L., Danbolt, J., \& Holland, J. (2014). Rethinking bank business models: the role of intangibles. Accounting, Auditing \& Accountability Journal, 27(3), 563-589.

Chen, M.-C., S.-J. Cheng, \& Y. Hwang. (2005). An empirical investigation of the relationship between intellectual capital and firms' market value and financial performance. Journal of Intellectual Capital, 6(2), 159-176

Clarke, D. C. 2004. The independent director in Chinese corporate governance. Working paper. University of Washington School of Law, Seattle, Wash.

Firer, S.; Williams, M. (2003) Intellectual capital and traditional measures of corporate performance. Journal of Intellectual Capital, Vol. 4, 348-360

Ho, C. A., \& Williams, S. M. (2003). International comparative analysis of the association between board structure and the efficiency of value added by a firm from its physical capital and intellectual capital resources.

Hsiao C (2003). Panel Data Analysis - Advantages and Challenges. Sociedad de Estadıstica e Investigación Operativa Test (0000) Vol. 00, No. 0, pp. 1-63

Hsu, C.-Y., Hsiao, H.-F., \& Li, C.-A. (2009). Effect of board monitoring on corporate investment and firm performance. Northeast Decision Sciences Institute Proceedings, 60-66.

Hsu, Y.H., and Fang, W.C. 2009. "Intellectual Capital and New Product Development Performance: The Mediating Role of Organizational Learning Capability," Technological Forecasting and Social Change (76:5), Jun, pp. 664-677 
Joshi, M., Cahill, D., \& Sidhu, J. (2010). Intellectual capital performance in the banking sector: An assessment of Australian owned banks. Journal of Human Resource Costing and Accounting, 14(2), 151-170.

Kang, S.C., and Snell, S.A. 2009. "Intellectual Capital Architectures and Ambidextrous Learning: A Framework for Human Resource Management," Journal of Management Studies (46:1), Jan, pp. 6592.

Khalique et. al., M. K. (2012). Relationship of Intellectual Capital with the Organizational Performance of Commercial Banks in Islamabad, Pakistan. PhD Student, Faculty of Economics and Business, Universiti Malaysia Sarawak, 1-12.

Kong, E., and Thomson, S.B. 2009. "An Intellectual Capital Perspective of Human Resource Strategies and Practices," Knowledge Management Research E Practice (7:4), Dec, pp. 356-364

Longo, M., Mariani, M.M., and Mura, M. (2009). "The Effect of Intellectual Capital Attributes on Organizational Performance. The Case of the Bologna Opera House," Knowledge Management Research \& Practice (7:4), Dec, pp. 365-376

OECD/Eurostat (2005), Oslo Manual, Guidelines for Collecting and Interpreting Innovation Data, Paris: OECD.

Phusavat, K., Comepa, N., Sitko-Lutek, A., and Ooi, K.B. (2011). "Interrelationships between Intellectual Capital and Performance Empirical Examination," Industrial Management \& Data Systems (111:56), pp. 810-829

Pulic, A. (2001), -VAICTM - An Accounting Tool for IC Management II, International Journal Technology Management, Vol.20, No.5/6/7/8, pp. 702-714.

Sardo, F.; Serrasqueiro, Z. A. (2015). European empirical study of the relationship between firms' intellectual capital, financial performance and market value. Journal of Intellectual Capital. 2017, 18, $771-778$

Sharabati, A.A.A., Jawad, S.N., and Bontis, N. 2010. "Intellectual Capital and Business Performance in the Pharmaceutical Sector of Jordan," Management Decision (48:1-2), pp. 105-131.

Shih, K. H., Chang, C. J., \& Lin, B. (2010). Assessing knowledge creation and intellectual capital in banking industry.

Stewart, T. A. 1997. The wealth of knowledge - Intellectual capital and the 21st

Tan, H. P.; Plowman, D.; Hancock, P. 2007. Intellectual capital and financial returns of companies, Journal of Intellectual Capital 8(1): 76-95.

Teece, D., Pisano, G. and Shuen, A. (1997). 'Dynamic capabilities and strategic management'. Strategic Management Journal, 18, 509-533.

Ting, I W, \& Lean, H H 2009, 'Intellectual capital performance of financial institutions in Malaysia', Journal of Intellectual Capital, Vol.10, No. 4, pp.588-599

Tobin, J. (1969). A general equilibrium approach to monetary theory. Journal of Money Credit and Banking $1(1), 15-29$. 